Environmental Management

Elsevier Editorial System(tm) for Journal of

Manuscript Draft

Manuscript Number: JEMA-D-18-00556R2

Title: The adoption of sustainable practices: A supplier's perspective

Article Type: Research Article

Keywords: Sustainable supply chain management; supplier development; knowledge base; power; absorptive capacity

Corresponding Author: Dr. Lingxuan Liu, Ph.D

Corresponding Author's Institution:

First Author: Lingxuan Liu, Ph.D

Order of Authors: Lingxuan Liu, Ph.D; Min Zhang; Weili Ye

Abstract: Suppliers' adoption of sustainable practices plays a critical role for global companies to improve environmental performance. Based on the absorptive capacity theory, this study empirically explores how suppliers' knowledge bases and power relationships influence their adoption of sustainability practices. A longitudinal case study with eight suppliers has been conducted. We find that the adoption of leading sustainable practices requires a supplier's good knowledge base whereas a supplier can adopt imitating and toddling sustainable practices even if it has a limited knowledge base. Both the power of internal sustainability teams and external buyers enhance the effects of suppliers' knowledge bases on the adoption of sustainable practices. Suppliers choose the strategy used in adopting sustainable practices according to the configuration of internal and external power. The results enhance current understandings of the mechanisms through which knowledge bases and power relationships affect the adoption of sustainable practices. The findings can also help global companies improve the effectiveness of their supplier development efforts and enhance the environmental performance of supply chains. 
The adoption of sustainable practices: A supplier's perspective

Lingxuan $\operatorname{Liu}^{1}$, Min Zhang ${ }^{2}$, Weili Ye ${ }^{3}$

1. Lancaster University Management School, Lancaster University, Bailrigg, Lancaster, UK

2. Norwich Business School, University of East Anglia, Norwich, Norfolk, UK

3. Chinese Academy of Environmental Planning, Beijing, China

* corresponding author

Lingxuan.liu@lancaster.ac.uk

Lancaster University Management School

LA1 4YX

United Kingdom

Declarations of interest: none 


\section{COVER LETTER}

Dear Editor,

We would like to resubmit the enclosed manuscript which we hope to be considered for publication as a research article in Journal of Environmental Management.

Thanks so much for providing us with the chance to revise and resubmit the paper. We have reduced the length of our manuscript from 27 pages to 23 pages. In doing so, we have also moved part of our tables from the manuscript to the Appendix, and completed another round of language check per the reviewers comments.

Best Regards.

Your Sincerely,

Dr Lingxuan Liu

Lancaster University

+4401524594895

Lingxuan.liu@lancaster.ac.uk

$09 / 10 / 2018$ 
Reviewer \#1:

The manuscript has been improved and I have obtained satisfactory answers to my questions and comments.

The manuscript still needs a thorough copy editing. Its language could be much improved.

Response:

Thank you very much. We have completed another round of thorough copy-editing. Your insights and contribution to our paper is much appreciated.

Reviewer \#2: The authors have successfully addressed my comments. I hope the editorial members find the work to be of value so that the paper can be accepted and published.

Response:

Thank you for all your useful comments. 
JEMA-D-18-00556R1

Highlights:

- Absorptive capacity is crucial for environmental management performance

- A supplier's knowledge base is critical for adoption of sustainable practices.

- The power of sustainability team will enhance the effect of good knowledge base

- The power of dominant buyer will enhance the effect of good knowledge base

- Internal and external power outlines the env. management strategy of suppliers 


\title{
The adoption of sustainable practices: A supplier's perspective
}

\author{
Abstract \\ Suppliers' adoption of sustainable practices plays a critical role for global companies to \\ improve environmental performance. Based on the absorptive capacity theory, this study \\ empirically explores how suppliers' knowledge bases and power relationships influence their \\ adoption of sustainability practices. A longitudinal case study with eight suppliers has been \\ conducted. We find that the adoption of leading sustainable practices requires a supplier's \\ good knowledge base whereas a supplier can adopt imitating and toddling sustainable \\ practices even if it has a limited knowledge base. Both the power of internal sustainability \\ teams and external buyers enhance the effects of suppliers' knowledge bases on the adoption \\ of sustainable practices. Suppliers choose the strategy used in adopting sustainable practices \\ according to the configuration of internal and external power. The results enhance current \\ understandings of the mechanisms through which knowledge bases and power relationships \\ affect the adoption of sustainable practices. The findings can also help global companies \\ improve the effectiveness of their supplier development efforts and enhance the \\ environmental performance of supply chains.
}

Keywords: Sustainable supply chain management; supplier development; knowledge base; power; absorptive capacity 


\section{Introduction}

Global companies have realized that sustainable supply chain management (SSCM) is critical for both business success and environmental performance improvement (Gereffi and Lee 2012). However, the sustainable management of global supply chains has been considered both crucial and challenging (Carter and Easton 2011, Agi and Nishant 2017) because supply chains are inherently complex and dynamic. Despite researchers and practitioners have made significant efforts to examine the environmental (Acquaye et al. 2017) and social (Sancha et al. 2015) impacts of supply chains, the practical solutions towards SSCM are yet to be developed (Markman and Krause 2016).

Suppliers' adoption of sustainable practices plays a critical role for a buyer to improve environmental performance. Buyers rely on supplier development initiatives to encourage and drive their suppliers to implement sustainable practices (Sancha et al. 2015, Zimmer et al. 2016). Although supplier development is a mature practice in supply chain management (Krause et al. 2000), supplier development for sustainability is relatively new, and has been implemented in different ways. It usually includes key activities such as competitive pressure, incentives, management involvement, evaluation and assessment, and knowledge transfer (Modi and Mabert 2007, Dou et al. 2015). Recent studies have made efforts to investigate the drivers (Sancha et al. 2015) and measurement (Bai and Sarkis 2010, Lu et al. 2012) of supplier development for sustainability, but it has been challenging to explain the various outcomes of supplier development initiatives. Specifically, different suppliers that have gone through similar supplier development initiatives appear to have distinct performance in the adoption of sustainable practices (Busse et al. 2016, Rodríguez et al. 2016). Such challenges have led to an obstacle for SSCM: global companies might fail to understand why some suppliers have successfully adopted sustainable practices while others have not, which brings increasing uncertainties to their strategies of investing resources into supplier development initiatives, such as training workshop, audit and certification, and product co-design (Zhu et al. 2013). Despite such an obstacle, most of the existing studies focus on buyers' design and provision of supplier development initiatives (Zimmer et al. 2016, Zhang et al. 2017, Liu et al. 2018). There is limited empirical evidence on the factors that affect suppliers' adoption of sustainable practices from a supplier's perspective.

Absorptive capacity (AC) refers to a firm's ability to recognize the value of new information, assimilate it, and apply it to commercial ends (Cohen and Levinthal 1990). It enables a firm to obtain and utilise knowledge to gain and sustain competitive advantages (Lane and 
Lubatkin 1998, Zahra and George 2002). Researchers have found that AC helps a firm learn new processes, practices, and skills from supply chain partners which improve the firm's performances and capabilities (Nagati and Rebolledo 2012, Zhang et al. 2015). Scholars have also been using the concept to examine firms' sustainability strategies and practices. For example, studies have found that suppliers' knowledge on sustainability management tools, technologies, and practices (Horisch et al. 2015) and receptivity on new ideas about innovations on sustainable operations (Gavronski et al. 2012) are critical for the suppliers to adopt sustainable practices. The theory of AC argues that a firm's knowledge base (i.e. access to external knowledge and prior relevant knowledge) affects its ability to learn from partners (Lane and Lubatkin 1998, Zahra and George 2002) and that the inter- and intraorganizational power relationships also influence a firm's capability to absorb the knowledge obtained from buyers (Todorova and Durisin 2007, Yeung et al. 2009). Therefore, knowledge bases and power relationships could provide an explanation for the puzzles about suppliers' adoption of sustainable practices (Williander 2007).

We design a multi-case, longitudinal study to explore suppliers' adoption of sustainable practices in the electronics industry. This industry faces many environmental (e.g. water usage, energy, water pollutants, hazardous waste, and materials and recycling) challenges on SSCM (Lau and Wang 2009, Lau and Wang 2009, Marques et al. 2013). Meanwhile, most of the solutions for SSCM rely on the improvement of suppliers' sustainable practices and capabilities. For example, both Apple ${ }^{1}$ and Samsung ${ }^{2}$ publicly acknowledge that their suppliers contribute to the majority of the carbon footprint of their products, and they are working with suppliers to reduce such emissions.

The objective of this study is to develop a framework that helps understand the phenomenon of suppliers' adoption of sustainable practices and identify key factors that facilitate suppliers' adoption of sustainable practices. Specifically, we aim to answer two specific questions: RQ1. How does a firm's knowledge base, including prior relevant knowledge and access to external knowledge, influence the adoption of sustainable practices?

RQ2. How do a firm's internal and external power relationships affect the adoption of sustainable practices?

\footnotetext{
${ }^{1}$ https://www.apple.com/environment/climate-change/

${ }^{2}$ http://www.samsung.com/us/aboutsamsung/sustainability/sustainablemanagement/environment/greenpolicy/
} 


\section{Literature review and conceptual framework}

Supplier development plays essential roles for a supplier to learn sustainable practices, but most of the existing studies focus on buyers' efforts in building sustainable supply chains. Few studies have taken a supplier's perspective and investigated the factors that influence a supplier's capabilities to acquire tools and practices to improve sustainability. For example, Styles et al. (2012) argue that supplier improvement programmes based on performance benchmarking and dissemination of better management practices can improve the sustainability of product supply chains. Ahmad et al. (2016) find that supplier and logistics management is vital to the achievement of sustainable oil and gas supply chains. Chkanikova (2016) reveals that power dependence in relationships with suppliers enables buyers to manage the environmental and social performance of procured goods in food supply chains. Zhang et al. (2017) find that pharmaceutical companies can develop supply chain social responsibility by applying supplier development practices. Liu et al. (2018) establish a conceptual four-stage framework to analyse the collaborative mechanisms of supplier development practices in SSCM. Researchers have found that sustainable manufacturing practices have been widely adopted in the electronics industry. For example, Lau and Wang (2009) examine the implementation of reverse logistics in the Chinese electronics industry. Lee and Kim (2009) show that environmental pressures and standards are widely accepted and implemented for supply management in the Korean electronics industry. Duan et al. (2011) discuss the dismantling of printed circuit board assemblies and the environmental consequences. Marques et al. (2013) investigate the different alternatives for recycling the printed circuit boards.

Based on the AC theory, we argue that suppliers' knowledge bases (access to external knowledge and prior relevant knowledge) positively affect their adoption of sustainable practices, and such impacts are influenced by the internal and external power relationships. This theory provides a useful lens for investigating how a firm utilizes external knowledge to develop capabilities and improve operations (Lane and Lubatkin 1998, Zhang et al. 2015). It enables us to understand the factors that affect the effectiveness of suppliers' learning from buyers and why similar supplier development programs may lead to different outcomes. Specifically, the theory proposes that a firm's knowledge base influences the process by which the firm interprets new knowledge and acts upon it (Zahra and George 2002). It also affects a firm's abilities to process and absorb externally generated knowledge, which 
eventually determines the intensity and speed of knowledge acquisition and implementation (Cohen and Levinthal 1990). Power refers to the ability of an actor to influence the decisions of another actor (Zhao et al. 2008). Buyers and internal employees may have power because they have specific knowledge or expertise, retain natural rights, and can provide reward or punishment (Yeung et al. 2009). The theory of AC argues that power relationships can explain why a firm uses only some of the available new knowledge and why some firms are better able to exploit external knowledge (Todorova and Durisin 2007). Buyers and internal employees can use its power to influence a firm's behaviour to obtain preferred outcomes. Power plays a critical role in enabling the exploitation of new knowledge by influencing resource allocation processes.

Access to external knowledge sources, such as supply chain partners, competitors, and universities and research institutes, improves the breadth and scope of a firm's knowledge bases on sustainable operations (Williander 2007, Zhang et al. 2015). Exposure to diversified external knowledge sources can influence a firm's decision making and the development of future capabilities on sustainability (Zahra and George 2002, Liu et al. 2017). It also helps a firm obtain know-how on SSCM which can improve the knowledge complementarity between the firm and buyers (Cohen and Levinthal 1990, Tu et al. 2006). External knowledge sources thus facilitate a firm to implement the knowledge on sustainability learned from buyers. Prior relevant knowledge reflects the job skills, technologies, and management practices about SSCM possessed by employees (Tu et al. 2006). It forms a foundation for knowledge transfer in supply chains and significantly affects the locus of a firm's technological search and investments (Cohen and Levinthal 1990, Nagati and Rebolledo 2012). Employees with successful past experiences and skills on sustainable operations help a firm learn new technologies, processes, and practices on sustainability from buyers (Williander 2007, Gavronski et al. 2012). Therefore, we argue that access to external knowledge and prior relevant knowledge can help a supplier learn from buyers and thus are positively associated with the adoption of sustainable practices.

Buyers can use power in a supply chain relationship to influence suppliers' decisions and behaviour on sustainable operations and to ensure that suppliers will follow their instructions and requirements (Zhao et al. 2008, Chkanikova 2016). Buyers can also use power to motivate suppliers to invest resources in learning, to adopt new technologies and processes that may significantly change suppliers' current operations to become compliant with the 
buyers' criteria on sustainability (Todorova and Durisin 2007, Horisch et al. 2015). Thus, them to achieve their goals on sustainability (Zhao et al. 2008). Moreover, the power of internal sustainability teams can facilitate the assimilation and exploitation of the acquired knowledge within a firm (Todorova and Durisin 2007). Powerful employees can overcome the lack of consensus and reach fast decisions on how to improve the sustainability of current operations and promote innovations that can improve environmental and social performance even when the innovations require a lot of investments (Zhao et al. 2008, Yeung et al. 2009). Power also allows sustainability teams to use their knowledge and experiences better to interpret and distribute the knowledge acquired from external sources to internal colleagues and then implement the knowledge to achieve preferred outcomes on sustainable development (Zahra and George 2002, Chkanikova 2016). Thus, internal power can facilitate suppliers to reap the value of knowledge on sustainability. Therefore, we argue that both external and internal power influence the impacts of suppliers' knowledge bases on the adoption of sustainable practices. The following framework is proposed to guide the case study (Figure 1).

\section{Insert Figure 1 here}

\section{Research method}

The adoption of sustainable practices is a dynamic process with high concerns of business confidentiality, and has limited empirical evidence (Sancha et al. 2015). As a result, the investigation is explorative in nature and we adopted a multiple case study method with a longitudinal design (Yin 2009). The method has been widely applied in qualitative sustainability research to understand emerging phenomenon and interdisciplinary problems.

\subsection{Research context}

BCA (i.e. buyer company A) is a leader in the electronics industry with well-recognized SSCM reputation and experiences. It regularly publishes sustainability reports which include sustainable supply chain strategies, and it continually invests in SSCM. The sustainability issues have been a key element of its supplier development initiatives for several years (see Appendix). The suppliers of BCA who went through various supplier development initiatives have shown various outcomes of the adoption of sustainable practices. Therefore, BCA provides a suitable research context to explore suppliers' adoption of sustainable practices. 


\subsection{Case selection}

The case selection process aims to create a theoretical sample in the supplier community of BCA with both diversity and coherency (Yin 2009). The unit of analysis is at the supplier facility level because the facilities are directly responsible for supplying BCA and the targets of BCA's supplier development initiatives.

We selected cases according to three criteria. First, the suppliers must have been directly supplying BCA for at least five years, and have committed to enrol in an 18-month supplier development initiative hosted by BCA. Not all suppliers were enrolled at the same time, but all enrolled suppliers started their 18-month training after July 2014, and completed before July 2016. Such case selection ensures that all cases share a level of similarity and comparability regarding the acquisition of knowledge as well as the buyer's requirements on sustainable practices. Second, we sampled through multiple product categories, so that the cases represent different product characteristics and manufacturing processes, and the sample has a distinct profile regarding suppliers' size, annual sales, and ownership. Third, we selected the sample by ensuring that BCA is not the only buyer of them. Eventually, eight suppliers were included in the final sample. The sample reflects a buyer-supplier community that is active in supplier development initiatives, and is evidently in improving their sustainability performance. Table 1 provides the profile of supplier facilities in the sample.

\section{Insert Table 1 here}

\subsection{Data collection}

We used semi-structured interviews to collect data before and after the 18-month supplier development initiative. At the beginning of the initiative (February 2015), we revealed ourselves as independent inspectors to gather information from suppliers through a group interview. At the closure of the initiative (July to September 2016), each enrolled supplier was required to formally report to BCA on what sustainable practices had been adopted during the past 18 months, and to present outcomes through a closed-door workshop. Interviews were conducted in the workshop. To develop the interview protocols, we worked closely with BCA and other stakeholders to understand the scope and objectives of the supplier development initiative. We designed interview questions based on 1) existing literature of SSCM and the framework developed in Figure 1;2) the training materials of the initiatives, which provide sustainability knowledge and best practices to suppliers; and 3) the 
evidence of sustainable practices adoption provided by the suppliers at the closure workshop (e.g. reports and presentation). The key interview questions focus on the following aspects:

- The prior knowledge of both individuals (e.g. academic background, environmental management experiences, knowledge of SSCM, etc.) and organisations (e.g. environmental certifications, green production systems, etc.) on sustainable practices;

- The main sources and approaches for suppliers to access external knowledge of sustainability issues;

- The managerial roles, responsibilities and structure of tackling environmental and social sustainability issues in the suppliers, as well as the specific roles of sustainability teams (if any);

- The formal and informal buyer-supplier interactions, including supplier development experiences, buyer auditing, regular monitoring, and communication.

Details of the interviews are summarized in the Appendix. The interviewees included: 1) gatekeepers, i.e., the individuals (usually suppliers' mid-level managers) that are directly involved in the supplier development initiatives organized by BCA; 2) suppliers' senior management, i.e., the leaders who oversee the operations of the facility and directly supervise the gatekeepers; and 3) suppliers' staff members and frontline workers. We selected gatekeepers based on the following criteria: 1) they have working experiences in the facility between 3 to 15 years, and at least two years in sustainability-related management; 2) they have been managing and leading at least one project in the past 18 months that has led to the improvement of sustainability performance; and 3) they have experiences for engaging and interacting with buyers. Interviews were documented in real-time, and then verified and checked by the interviewees and research team.

We also used multiple sources of information to triangulate the data. Besides interviews and observations by the research team, other sources included the publicly available reports regarding sustainability and corporate social responsibility of BCA, as well as the documents, slides, and materials prepared by the eight suppliers to introduce their sustainability strategies and practices. The triangulation enables the research team to: 1) analyse suppliers' knowledge bases related to sustainability issues; 2 ) understand the power of sustainability teams in supplier facilities and the power of BCA; 3) obtain evidence of the adoption of sustainable practices as a direct or indirect outcome of supplier development programs. 


\section{Analysis and results}

Open coding and pattern matching methods are used to analyse the data (Yin 2009). The coded data is verified with the industrial knowledge of: 1) the research team, 2) BCA's sustainability team, and 3) the external experts that are responsible for knowledge exchange and training delivery of the 18-month supplier development initiative. The pattern matching process takes in the key narratives generated from coded data, including repeating keywords and highlighted reflections from the case suppliers, and match those narratives with the constructs of knowledge bases and power relationship. The case evidence related to the adopted sustainable practices and suppliers' knowledge bases and power relationships are presented in the Appendix. Detailed metrics of evaluating the sustainable practices, knowledge bases, and powers, can also be founded in the Appendix.

\subsection{Suppliers' adoption of sustainable practices}

We analysed the sustainability-related practices and activities in the eight cases both before and after the 18-month supplier development initiative to identify the sustainable practices that have been adopted in the supplier facilities. This ensures that the new practices and ideas are the results of BCA's supplier development initiatives. We find that the suppliers have adopted three kinds of sustainable practices: leading, imitating, and toddling practices. A leading sustainable practice is usually innovative, and sometimes involves large investments in technological or systematic changes at facility level. An imitating sustainable practice usually undergoes a fast learning process, and the supplier adopts good or advanced practices from existing industrial cases to meet its business and sustainability requirements. A toddling sustainable practice usually finds out the low-hanging fruit among all sustainability solutions, thus a supplier tries to adopt those low-costing, feasible practices as soon as possible. All three kinds of sustainable practices lead to sustainability performance improvement at the suppliers' facilities.

\subsection{Role of knowledge base}

Our analysis implies that the supplier's prior knowledge on sustainability resides on both individual levels (employees' skills and expertise) and organizational levels (capabilities to manage process, system, and people) (see Appendix). They eventually lead to better sustainability performance. The very idea of sustainability is comprehensive and keeps evolving, leading to a result that five out of eight suppliers confessed that they considered themselves "have limited knowledge or access to the knowledge of sustainability". For example, S2, S4, S7, and S8 agreed that they did not have a clear sustainability strategy other 
than "compliance with buyer and/or government requirements"; 22 out of the 30 interviewed gatekeepers claimed that their latest degrees and early career experiences were not closely related to environmental management, safety management, or work and health issues.

We find that supply chain members (e.g. buyers and peer suppliers) are the main sources of sustainability knowledge for the suppliers (see Appendix). We also find that the suppliers seek such knowledge to 1) remain competitiveness among peer suppliers; 2) meet the compliance requirements of governmental regulations and buyers, and 3) answer to sustainability-related concerns from the community, civil societies and media. However, gatekeepers from S2, S6, S7, and S8 agreed that they have limited sources of knowledge when trying to explore and learn sustainability to tackle challenges.

In general, the results show that the suppliers who possessed good prior knowledge about sustainability, and who can access external knowledge about sustainability feel it is less challenging to identify and implement sustainable practices. Such suppliers will also have a better chance to "focus on the innovative exploration on environmental management and sustainable manufacturing, instead of being a 'tinker' that struggles to make everything on the BCA checklist looks right." (Gatekeeper, S5)

In the meantime, all interviewees emphasized that there is a complicated process to transfer individual knowledge into organisational actions, which is related to the skills and roles of the gatekeepers. For example:

"It is almost impossible just to take the training materials that I got, come back to the factory, and simply teach my colleagues and workers with that - I will have to digest all that I have learnt and rewrite specific cases that are quite related to our work environment and everyday practices. The 'delivery' must be constant and can take months if not years." (Gatekeeper, S8)

\subsection{Role of power relationships}

We find that the power of suppliers' sustainability teams ${ }^{3}$ is critical to influencing the impacts of knowledge bases on the adoption of sustainable practices. The results reveal that, although the structure and culture of suppliers' sustainability teams are different, the power of a sustainability team can be measured by the following qualitative descriptions:

\footnotetext{
${ }^{3}$ The sustainability team includes gatekeepers and their co-workers who can be either full-time or part-time working on sustainability-related issues, e.g., a human resource manager is also in charge of the occupational health issues of workers, but she might spend only one day per week on the related work.
} 
1) their access and ability to influence facility leadership, either through reporting lines or personal relations;

2) they are regarded as the sustainability experts in the facility;

3) they have an overseeing role on sustainable practices of workers and production lines, and sometimes can provide rewards and incentives;

4) they are capable of acquiring sufficient budget to implement sustainable practices

We find that (see Appendix) powerful sustainability teams can use their power, so that the ideas, plans, and projects of sustainable practices learned from supplier development initiatives will have a better chance to be adopted and implemented to improve operations. For example,

“...He (the Gatekeeper) managed to convince me, that the budget used on facility refurbishment cannot be judged through a balance sheet - it is more like safety insurance." (Senior management, S3).

"Ms. ... (name of one of the Gatekeepers) leads the HR office. Although she is not my boss, her team has established a system ... so that the water \& energy efficiency is in our KPI. If my team is doing better than the rest of us (i.e., the manufacturing teams), I got 5\% more in my annual premium" (Operational director, S4).

The case evidence also suggests that BCA can use its power to influence suppliers' decisions. BCA's power is reflected by suppliers' dependence on BCA. Strong buyer power means that the suppliers are dependent on BCA's resources. The suppliers respect a natural, legitimate right from $\mathrm{BCA}$ to influence its business or the $\mathrm{BCA}$ can reward and punish the suppliers (quote, "they say jump, we say how far"). Weak buyer power means that suppliers have more autonomy in business and do not depend much on BCA, whereas the strategic relationship with BCA is still being valued (keywords quote, "collaboration", "partnership" or "codesigning”). We find that when BCA has strong power, it is demanding and drives suppliers to invest in assimilating and applying the knowledge and skills learned through the supplier development initiatives. When BCA has weak power, suppliers care less about BCA's supplier development initiatives. Suppliers' decisions are less influenced by BCA and they are less invested to absorb the knowledge learned through supplier development initiatives. 


\subsection{Impacts of knowledge bases and power relationships on suppliers' adoption of} sustainable practices

The findings related to the knowledge bases, power relationships, and adopted sustainability practices by the suppliers are summarized in Table 2 .

\section{Insert Table 2 here}

The result reveals that three suppliers (S1, S3, and S5) have good knowledge bases compared with the other five suppliers. They have also adopted leading sustainable practices whereas none of the other suppliers had. The finding thus suggests that a supplier's knowledge base plays a critical role for the supplier to adopt leading sustainable practices. The leading sustainable practices involve systematic changes in a suppliers' current processes and operations. Hence, the suppliers must redesign their products or processes, and doing so relies on existing knowledge and access to external knowledge. The case evidence further suggests that suppliers with limited knowledge bases can adopt imitating and toddling sustainable practices because those practices are relatively simple and do not involve significant changes in operations and processes. When adopting the imitating and toddling sustainable practices, suppliers only need to adjust existing practices and systems which relies on incremental innovation or improvement. In addition, we find that S1 and S5 have adopted more sustainable practices compared with S3, while BCA has weak power over S3 but strong power over S1 and S5. The findings indicate that BCA can use its power to drive suppliers to leverage their knowledge bases to adopt more sustainable practices, i.e., buyer power enhances the effect of a supplier's knowledge base on the adoption of sustainable practices. The evidence from S2, S4, and S8 also supports this finding: although they have limited knowledge bases, they all have adopted some imitating and toddling sustainable practices. This indicates that both internal sustainability teams and BCA can use their power to drive suppliers to exploit their knowledge bases to adopt sustainable practices. The evidence from S6 (both BCA and sustainable team have weak power) supports the finding as well. Hence, we argue that both the power of the sustainability teams and BCA can enhance the value of knowledge base on the adoption sustainable practices. Therefore, we develop the following propositions.

P1: A supplier's good knowledge base is critical for the adoption of leading sustainable practices. 
P2: A supplier can adopt imitating and toddling sustainable practices even if it has a limited knowledge base.

P3: The effects of a supplier's knowledge base on the adoption of sustainable practices are enhanced by both the power of internal sustainability team and external buyer.

The case evidence reveals that the power of sustainable team and buyer also affect a supplier's strategy used in sustainable practices adoption. We find that a supplier can use the following strategies within the given configuration of internal and external power (Figure 2):

- Innovator: a strategy that "introduces technologies that improve both efficiency and sustainability, and cares about workers' economic and social benefits. There will be no ground-level implementation of any practices if they (the workers) cannot benefit in both ways." (S1 and S5)

- Explorer: a strategy that "repeatedly ask ourselves 'what are the mandatory and voluntary standards from BCA, government or whatever likely to be ten years from now?', and then make our resources available to remain competitiveness, " (S3) and that "think out of the box, always ask around, and be adaptive to find solutions." (S7)

- Enforcer: a strategy when a buyer's requirements on sustainability are perceived as "stringent, straightforward, and instructive" (S8) and the investments into sustainability practices are "an environmental safeguard" (S4) and "can hardly be considered through a cost-benefit mindset." (S2)

- Tinker: this quote speaks for itself - “...Just let us know what are the problems, what are the metrics, and we will improve them, hopefully in time." (S6)

\section{Insert Figure 2 here}

The results reveal that sustainability teams and BCA have strong power in S1 and S5. BCA thus can use its power to drive S1 and S5 to invest in more resources to the adoption of sustainability practices and allocate more resources to the sustainability teams. The resources not only enable S1 and S5 to develop process innovations during the adoption but also allow the sustainability teams to better transfer the practices within S1 and S5. In addition, the sustainability team can also use its power to ensure the transformation of individual knowledge to organizational actions and that the new practices and process innovations can be successfully implemented and distributed within its facility. Therefore, the internal and 
external power complements each other and they enable a supplier to adopt the innovator strategy. The sustainability teams in S3 and S7 have strong power whereas BCA has weak power. Because the sustainability teams have strong power, S3 and S7 view sustainability as critical issues and are proactive in adopting sustainability practices. They tend to develop sustainability practices based on their own needs and judgement and hence use the explorer strategy. BCA has strong power in S2, S4, and S8. Hence, BCA can use its power to drive them to adopt sustainable practices according to its requirements. However, because their sustainability teams have weak power, they may be reluctant to be proactive in sustainability issues or develop innovative practices. Hence, they use the enforcer strategy. For the supplier with weak internal power and buyer power (S6), BCA cannot drive it to adopt sustainability practices and it is also challenging for the sustainability team to promote and distribute advanced sustainability practices. S6 thus passively responds to the sustainability concerns and crisis, and uses the tinker strategy. Therefore, we develop the following proposition.

P4: The strategy a supplier used for adopting sustainable practices is affected by the configuration of internal and external power.

\section{Discussion and conclusions}

\subsection{Theoretical contributions}

We reveal that suppliers may learn leading, imitating, and toddling sustainable practices and the adoption of different practises are influenced by suppliers' knowledge bases and power relationships. The findings extend current literature on supplier development by providing a possible explanation on why global companies' supplier development initiatives may fail (Busse et al. 2016, Rodríguez et al. 2016) and by revealing when a global company's supplier development initiatives are more effective from a supplier's perspective (Modi and Mabert 2007, Bai and Sarkis 2010, Lu et al. 2012). This study also offers theoretical reasoning and empirical evidence that a supplier's AC plays a critical role in adopting sustainable practices, extending existing understandings on the consequences and performance outcomes of AC (Williander 2007, Nagati and Rebolledo 2012, Tu et al. 2006).

Our findings clarify the mechanisms through which a supplier's knowledge base affects the adoption of sustainable practices. We find that a good knowledge base is critical for the adoption of leading sustainable practices whereas the impacts of knowledge bases on the 
adoption of imitating and toddling sustainable practices are not significant. The result is consistent with the argument that the effect of a firm's AC is contingent on the interorganizational learning context (Lane and Lubatkin 1998, Nagati and Rebolledo 2012). It extends current studies on the antecedents of SSCM, which mainly takes a buyer's perspective (Lau and Wang 2009, Styles et al. 2012, Dou et al. 2015) or focuses on institutional pressures (Zhu et al. 2013, Ye et al. 2013, Wu et al. 2013).

We also reveal the mechanisms through which the internal power of the sustainability team and external power of buyer affect the adoption of sustainable practices. We find that both internal and external power enhance the impacts of knowledge bases on the adoption of sustainable practices. Power relationships and knowledge bases are not independent, and researchers should adopt a contingency perspective when considering their interaction effects in promoting SSCM, enhancing current understandings of the consequences of power in supply chain relationships (Zhao et al. 2008, Yeung et al. 2009). Under certain conditions, a supplier's knowledge base has greater impacts on the adoption of sustainable practices and is more effective than that of its rivals (Zahra and George 2002). The results suggest that a supplier will implement four strategies to adopt sustainable practices according to the configuration of internal and external power. The finding links a firm's internal and external power and provide empirical evidence that a configurative perspective should be used to investigate the impacts of power relationships on the adoption of SSCM, improving existing knowledge on how to develop a sustainable supply chain (Williander 2007, Chkanikova 2016).

\subsection{Managerial implications}

The research provides guidelines for companies on how to improve the sustainability of their supply chains. First, we suggest global companies provide different levels of sustainable practices when designing supplier development initiatives (Liu et al. 2018, Zhang et al. 2017). Second, we suggest suppliers invest in developing a good knowledge base for adopting leading sustainable practices (Cohen and Levinthal 1990, Tu et al. 2006). Specifically, suppliers should hire employees with good education background and previous work experiences in sustainability. They should also invest in environmental management systems (e.g. ISO 14000), develop the code of conduct, and build a system to record previous experience in supplier development/compliance schemes. In addition, we suggest them develop tools and procedures to acquire knowledge from buyers (e.g. compliance requirements, environmental and social standards, and feedback from audits) and peer 
suppliers (e.g. best practices and cases, and risks and benefits of sustainable practices), and attend various formal and informal trainings. We also suggest suppliers actively participate in supplier development initiatives even if they do not have a good knowledge base, because they can learn from and implement imitating and toddling sustainable practices. Finally, we suggest that global companies should tailor their supplier development initiatives according to suppliers' knowledge bases.

Third, we suggest suppliers improve the power of sustainability teams and buyers use their power to drive suppliers to invest in the adoption of sustainable practices and improvement of knowledge bases on sustainability (Chkanikova 2016, Yeung et al. 2009). For example, the team members should be provided with access to leadership through reporting lines and have an overseeing role on sustainable practices of workers and production lines. They should also be allocated with sufficient budget to implement sustainable practices and be authorized to correct unsustainable behaviours. Global companies may require their suppliers to send gatekeepers to training programs to improve their capabilities and to build information and database systems and operational procedures to keep past experiences and best practices on sustainable development. In addition, global companies could strengthen buyer-supplier relationships through contracting, certification, and other supplier engagement activities to improve their power.

Fourth, we suggest suppliers select the strategy for adopting sustainable practices according to the configuration of internal and external power. Specifically, when both internal sustainability teams and buyers have strong power, suppliers could use the innovator strategy to take leadership in the adoption of sustainable practices. If only internal sustainability teams have strong power, suppliers could use the explorer strategy to be proactive in the development of SSCM. If only a buyer has strong power, suppliers could use the enforcer strategy to focus on adopt the sustainability practices by the buyer's requirements and standards to manage sustainability risks. When the power of both internal sustainability teams and buyer are weak, suppliers could use the tinker strategy to adopt sustainable practices passively in response to sustainability concerns.

\subsection{Limitations and future research directions}

This study has limitations which open avenues for future research. First, this study uses a longitudinal case study approach and the data is collected from eight suppliers of an electronics company. Therefore, the generalizability of the findings is a limitation. Future 
studies could conduct large-scale surveys to test and validate the propositions empirically. Second, researchers argue that $\mathrm{AC}$ involves learning processes including acquisition, assimilation, and application (Zahra and George 2002, Zhang et al. 2015). Exploring the impacts of the learning processes on the adoption of sustainability practices in supply chains could be an interesting topic. Third, researchers argue that the social capital within an organization and supplier-buyer relationships, such as trust and justice, may influence knowledge transfer and implementation (Yeung et al. 2009, Wu et al. 2012). Future studies could investigate the effects of social capital on SSCM. Fourth, researchers have found that institutional pressures play crucial roles in the adoption of SSCM. Future studies could explore how the impacts of AC on SSCM are influenced by institutional pressures (Hoejmose et al. 2012, Zhu et al. 2013). Fifth, this study focuses on the impacts of knowledge bases and power relationships on suppliers' adoption of sustainable practices. A supplier can learn new knowledge and skills through supplier development, which may influence the supplier's knowledge bases and power relationships in the long term (Cohen and Levinthal 1990). Future studies could explore the impacts of supplier development initiatives on suppliers' knowledge bases and power relationships.

\section{References}

Acquaye, A., K. S. Feng, E. Oppon, S. Salhi, T. Ibn-Mohammed, A. Genovese and K. Hubacek (2017). "Measuring the environmental sustainability performance of global supply chains: A multi-regional input-output analysis for carbon, sulphur oxide and water footprints." Journal of Environmental Management 187: 571-585.

Agi, M. A. N. and R. Nishant (2017). "Understanding influential factors on implementing green supply chain management practices: An interpretive structural modelling analysis." Journal of Environmental Management 188: 351-363.

Bai, C. and J. Sarkis (2010). "Green supplier development: Analytical evaluation using rough set theory." Journal of Cleaner Production 18(12): 1200-1210.

Busse, C., M. C. Schleper, M. L. Niu and S. M. Wagner (2016). "Supplier development for sustainability: Contextual barriers in global supply chains." International Journal of Physical Distribution \& Logistics Management 46(5): 442-468.

Carter, C. R. and L. Easton (2011). "Sustainable supply chain management: Evolution and future directions." International Journal of Physical Distribution \& Logistics Management 41(1): 46-62. 
Chkanikova, O. (2016). "Sustainable purchasing in food retailing: Interorganizational relationship management to green product supply." Business Strategy and the Environment 25: 478-494.

Cohen, W. M. and D. A. Levinthal (1990). "Absorptive capacity: A new perspective on learning and innovation." Administrative Science Quaterly 36: 128-152.

Dou, Y., Q. Zhu and J. Sarkis (2015). "Integrating strategic carbon management into formal evaluation of environmental supplier development programs." Business Strategy and the Environment 24: 873-891.

Duan, H., K. Hou, J. Li and X. Zhu (2011). “Examining the technology acceptance for dismantling of waste printed circuit boards in light of recycling and environmental concerns." Journal of Environmental Management 92: 392-399.

Gavronski, I., R. D. Klassen, S. Vachon and L. F. M. do Nascirnento (2012). "A learning and knowledge approach to sustainable operations." International Journal of Production Economics 140(1): 183-192.

Gereffi, G. and J. Lee (2012). "Why the world suddenly cares about global supply chains." Journal of Supply Chain Management 48(3): 24-32.

Hoejmose, S., S. Brammerand and A. Millington (2012). " 'Green' supply chain management: The role of trust and top management in B2B and B2C markets." Industrial Marketing Management, 41:609-620.

Horisch, J., M. P. Johnson and S. Schaltegger (2015). "Implementation of sustainability management and company size: A knowledge-based view." Business Strategy and the Environment 24: 765-779.

Krause, D. R., T. V. Scannell and R. J. Calantone (2000). "A structural analysis of the effectiveness of buying firms' strategies to improve supplier performance." Decision Sciences 31(1): 33-55.

Lau, K.H. and Y. Wang (2009). "Reverse logistics in the electronic industry of China: A case study." Supply Chain Management: An International Journal 14: 447-465.

Lane, P. J. and M. Lubatkin (1998). "Relative absorptive capacity and interorganizational learning." Strategic Management Journal 19: 461-477.

Liu, L., M. Zhang, L. Hendry, S. Wang and M. Bu (2018). "Supplier development practices for sustainability: A multi-stakeholder perspective." Business Strategy and the Environment. 27:100-116. 
Lee, K. and J. Kim (2009). "Current status of CSR in the realm of supply management: The case of the Korean electronics industry." Supply Chain Management: An International Journal. 14: 138-148.

Lu, R. X. A., P. K. C. Lee and T. C. E. Cheng (2012). "Socially responsible supplier development: Construct development and measurement validation." International Journal of Production Economics 140(1): 160-167.

Markman, G. D. and D. Krause (2016). "Theory building surrounding Ssustainable supply chain management: Assessing what we know, exploring where to go." Journal of Supply Chain Management 52(2): 3-10.

Marques, A. C., J. M. Cabrera and C. D. Malfatti (2013). "Printed circuit boards: A review on the perspective of sustainability." Journal of Environmental Management 131: 298-306. Modi, S. B. and V. A. Mabert (2007). "Supplier development: Improving supplier performance through knowledge transfer." Journal of Operations Management 25(1): 42-64. Nagati, H. and C. Rebolledo (2012). "The role of relative absorptive capacity in improving suppliers' operational performance." International Journal of Operations \& Production Management 32: 611-630.

Rodríguez, J. A., C. Giménez Thomsen, D. Arenas and M. Pagell (2016). "NGOs’ initiatives to enhance social sustainability in the supply chain: Poverty alleviation through supplier development programs." Journal of Supply Chain Management 52(3): 83-108. Sancha, C., A. Longoni and C. Gimenez (2015). "Sustainable supplier development practices: Drivers and enablers in a global context." Journal of Purchasing and Supply Management 21(2): 95-102.

Shang, K., C., Lu and S. Li (2010). “A taxonomy of green supply chain management capability among electronics-related manufacturing firms in Taiwan.” Journal of Environmental Management 91: 1218-1226.

Styles, D., H. Schoenberger and J. Galvez-Martos (2012). "Environmental improvement of product supply chains: Proposed best practice techniques, quantitative indicators and benchmarks of excellence for retailers." Journal of Environmental Management 110: 135-150. Todorova, G. and B. Durisin (2007). "Absorptive capacity: Valuing a reconceptualization." Academy of Management Review 32(3): 774-786.

Tu, Q., M. A. Vonderembse, T. S. Ragu-Nathan and T. W. Sharkey (2006). "Absorptive capacity: Enhancing the assimilation of time-based manufacturing practice." Journal of Operations Management 24: 692-710. 
Williander, M. (2007). "Absorptive capacity and interpretation system's impact when 'Going Green': An empirical study of Ford, Volvo Cars." Business Strategy and the Environment 16: 202-213.

Wu, G., J. Ding and P. Chen (2012). "The effects of GSCM drivers and institutional pressures on GSCM practices in Taiwan's textile and apparel industry". International Journal of Production Economics 135:618-636.

Yeung, J. H. Y., W. Selen, M. Zhang and B. Huo (2009). "The effects of trust and coercive power on supplier integration." International Journal of Production Economics 120: 66-78. Yin, R. (2009). Case Study Research. Design and Methods, 4th edition Sage Publications, Inc. Ye, F., X. Zhao, C. Prahinski and Y. Li (2013). "The impact of institutional pressures, top managers' posture and reverse logistics on performance-Evidence from China". International Journal of Production Economics, 143:132-143.

Zahra, S. A. and G. George (2002). "Absorptive capacity: A review, reconceptualization, and extension." Academy of Management Review 27: 185-203.

Zhang, M., K. Pawar and S. Bhardwaj (2017). "Improving supply chain social responsibility through supplier development." Production Planning \& Control 26: 500-511.

Zhang, M., X. Zhao, M. Lyles and H. Guo (2015). "Absorptive capacity and mass customization capability." International Journal of Operations \& Production Management 35: 1275-1294.

Zhao, X., B. Huo, B. B. Flynn and J. H. Y. Yeung (2008). "The impact of power and relationship commitment on the integration between manufacturers and customers in a supply chain." Journal of Operations Management 26: 368-388.

Zhu, Q., J. Sarkis, and K. Lai (2013). “Institutional-based antecedents and performance outcomes of internal and external green supply chain management practices". Journal of Purchasing and Supply Management, 19:106-117.

Zimmer, K., M. Froehling and F. Schultmann (2016). "Sustainable supplier management - A review of models supporting sustainable supplier selection, monitoring and development." International Journal of Production Research 54(5): 1412-1442. 
Table 1 Profile of supplier facilities ${ }^{4}$

\begin{tabular}{|c|c|c|c|c|c|}
\hline $\mathrm{ID}^{5}$ & $\begin{array}{l}\text { Number of } \\
\text { employee }\end{array}$ & \begin{tabular}{|l|} 
Annual \\
sales \\
(\$ million)
\end{tabular} & $\begin{array}{l}\text { Location of } \\
\text { headquarter }^{6}\end{array}$ & Main products & Product categories of major buyers \\
\hline S1 & 3,000 & 100 & China & Magnetic materials & IT equipment; Medical devices; Automotive \\
\hline S2 & 10,000 & 300 & America & Plastics components & IT equipment \\
\hline S3 & 6,000 & 200 & Taiwan & Input devices & IT equipment \\
\hline S5 & 13,000 & 1,000 & Taiwan & Printed circuit board & EEE in general \\
\hline S6 & 3,000 & 200 & Japan & Metal products & EEE in general \\
\hline S7 & 2,000 & 100 & America & Printing \& Package & IT equipment; Cigarettes; Beverage \\
\hline
\end{tabular}

\footnotetext{
${ }^{4}$ Each supplier facility represents a single factory or plant in a single location that directly supplies to BCA.

${ }^{5}$ For confidentiality reason, we cannot disclose the names and facility locations of suppliers. Each supplier has been referred to by a sequential number.

${ }^{6}$ Registered parent companies or business groups, not the locations of the supplier facilities. There may or may not be other facilities of the same parent companies or business groups that are also supplying BCA.

${ }^{7}$ We used the EEE categories defined by UK government. see https://www.gov.uk/government/uploads/system/uploads/attachment_data/file/393740/LIT_7876.pdf
} 
Table 2 Cross-case comparison on knowledge base, power relationships and adoption of sustainable practices

\begin{tabular}{|c|c|c|c|c|c|c|}
\hline \multirow{2}{*}{ Supplier } & \multirow{2}{*}{ Knowledge base } & \multirow{2}{*}{$\begin{array}{c}\text { Power of } \\
\text { sustainability } \\
\text { team }\end{array}$} & \multirow{2}{*}{$\begin{array}{l}\text { Power of } \\
\text { buyer }\end{array}$} & \multicolumn{3}{|c|}{$\begin{array}{l}\text { Adoption of sustainable practices } \\
\text { (total number of projects) }\end{array}$} \\
\hline & & & & Leading & Imitating & Toddling \\
\hline S1 & Good & Strong & Strong & 2 & 4 & 1 \\
\hline $\mathrm{S} 2$ & Limited & Weak & Strong & 0 & 3 & 3 \\
\hline S3 & Good & Strong & Weak & 1 & 4 & 1 \\
\hline $\mathrm{S} 4$ & Limited & Weak & Strong & 0 & 2 & 2 \\
\hline S5 & Good & Strong & Strong & 3 & 3 & 2 \\
\hline S6 & Limited & Weak & Weak & 0 & 1 & 2 \\
\hline S7 & Limited & Strong & Weak & 0 & 4 & 1 \\
\hline S8 & Limited & Weak & Strong & 0 & 3 & 1 \\
\hline
\end{tabular}

The evaluation of "good" or "limited" knowledge bases is judged based on the content of reports and presentations submitted by the suppliers at the close-door workshop mentioned in Section 3.3. Key elements of evaluation includes: the accuracy and timeliness of sustainability issues captured, the specific approaches of identifying proper projects, and the expertise demonstrated in Q\&A session of the workshop.

The evaluation of "strong" or "weak" power of a sustainability team is based by the qualitative descriptions of: access to facility leadership, recognition as sustainability experts, authority to provide rewards and incentives; and access to budget.

The evaluation of "strong" or "weak" power of buyer (BCA) is based on business dependency.

See Appendix for more details and quotation as evidence. 


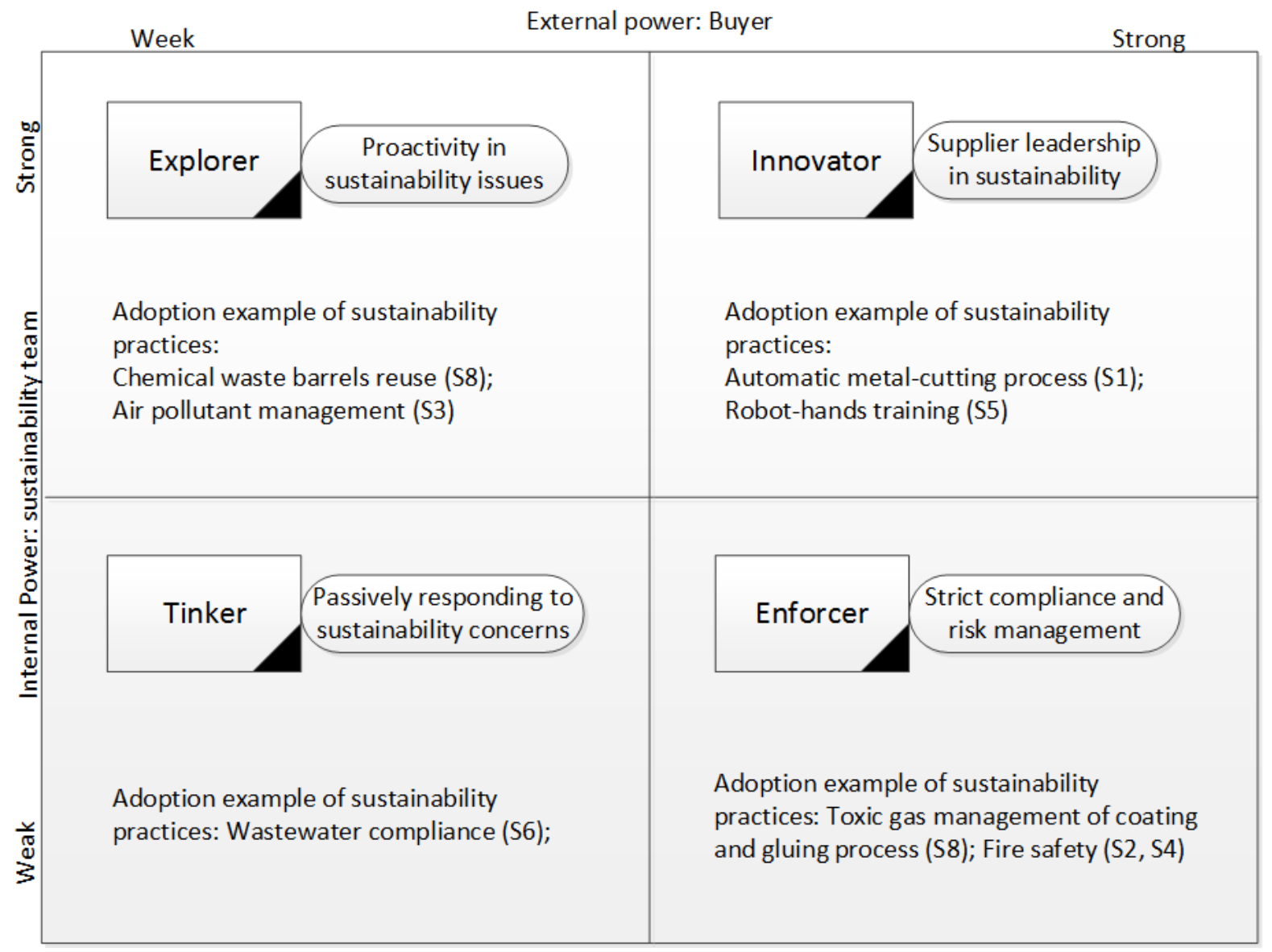

Figure 2 Four strategies of adopting sustainable practices 


\section{Appendix}

The adoption of sustainable practices: A supplier's perspective

\section{JEMA-D-18-00556}

1. The supplier development initiatives on sustainability issues of BCA's supply chains

The Supplier Environment, Health and Safety (EHS) Academy Program was launched by BCA in partnership with a few global and regional environmental non-profit organisations. It is a multi-year program focusing on BCA's suppliers/OEMs. The Program has been conducted across several geographic locations through two EHS Centres with the goal of educating sustainability professionals and improving sustainability performance and reducing health and safety risks in manufacturing facilities, through a rigorous training engagement provided to EHS managers. In roughly three years, The Program has engaged with 596 mid-level managers from 203 supplier facilities in EHS training and technical assistance activities.

Each participant was allowed to choose between one of two tracks: an environmental management track, or a health and safety (i.e., social sustainability) management track. There were 15 mandatory courses in common across both training tracks, four elective courses for the environmental track, and seven elective courses for the H\&S track. In each course, trainees were asked to attend classroom training sessions conducted by the EHS+ Centers, and then conducted onsite projects in their workplaces that applied their newly acquired knowledge and skills. Upon completion of all courses, trainees from each facility would deliver a presentation to summarize their achievements and lessons learned in the whole training cycle. The Program duration for each trainee is 18 months.

2. Summary of data collection

\begin{tabular}{|l|l|l|}
\hline \multicolumn{2}{|l|}{ Feb 2015} \\
\hline \multicolumn{2}{|l|}{ The gatekeepers (see below) from all suppliers were invited to attend a workshop, and were interviewed as a focus group. } \\
\hline July-Sept 2016 & $\begin{array}{l}\text { Senior management (8 } \\
\text { interviewees, each } \\
\text { interview lasts about 20- } \\
30 \text { minutes) }\end{array}$ & $\begin{array}{l}\text { Staff and worker: } \\
\text { (Focus group interviews without the presence } \\
\text { of gatekeepers or senior management) }\end{array}$ \\
\hline
\end{tabular}




\begin{tabular}{|c|c|c|c|}
\hline S1 & \begin{tabular}{|l|} 
Safety director \\
Safety manager $x 2$ \\
Environment manager $\mathrm{x} 2$ \\
\end{tabular} & General manager & \multirow{6}{*}{$\begin{array}{l}\text { - 20-30 minutes with a group of mid- } \\
\text { level managers (peers of gatekeepers, } \\
\text { but have operational/production duties } \\
\text { instead); } \\
\text { - } 20-30 \text { minutes with a group of line } \\
\text { leaders/workers; } \\
\text { - } 15-20 \text { minutes of facility tour and } \\
\text { informal discussion. }\end{array}$} \\
\hline S2 & $\begin{array}{l}\text { Environment manager } \\
\text { Quality assurance } \\
\text { Safety manager }\end{array}$ & Operational director & \\
\hline S3 & \begin{tabular}{|l|} 
Quality assurance \\
Sustainability manager $\times 2$
\end{tabular} & General manager & \\
\hline S5 & $\begin{array}{l}\text { Safety and health manager } \\
\text { Associate director of environment management } \\
\text { Environment manager } x 2 \\
\text { Safety manager }\end{array}$ & $\begin{array}{l}\text { Chair of health and safety } \\
\text { commission }\end{array}$ & \\
\hline S6 & $\begin{array}{l}\text { Environment manager } \\
\text { Quality assurance } \\
\text { Safety manager } \times 2 \\
\end{array}$ & Vice president & \\
\hline S8 & $\begin{array}{l}\text { Quality assurance } \\
\text { Sustainability manager }\end{array}$ & General manager & \\
\hline
\end{tabular}

3. Sustainable practices: leading, imitating and toddling

During the whole supplier development program, the participating suppliers completed over 1,000 onsite projects that are designed to improve facilitylevel EHS performance. The evaluation of those projects is based on the "before vs. after" of supplier sustainability performance through BCA's audit scores and data, in areas including: 
- Water efficiency

- Wastewater discharge

- Solid waste management

- Hazardous waste management

- Worker injury rates

- Accidents of fire, explosion and/or hazardous leakage

The examples of sustainable practices studied in this piece of research are provided in Table 3 . The judgement made to identify those practices as leading, imitating and toddling and based on three sets or criteria:

1) How much improvement of sustainability performance that a project (or several projects together) has led to in one supplier facility? The project will have to generate significant improvement to be categorized as a leading or imitating practice.

2) Whether such practices were introduced by the lecturers in the 18-month training sessions. A leading practice must be based on the innovativeness of supplier trainees or their ability to explore among external resources (thus not come from the classroom), while a imitating or a toddling practice can come from the classroom.

3) If the practice is about meeting the local (governmental) regulatory targets, it is categorized as toddling no matter how high the investment is or how effective is it. Because of the lack of innovativeness (i.e., the supplier should have done it with or without the requirement of BCA).

\begin{tabular}{|l|l|l|}
\hline \multirow{2}{*}{} & \multicolumn{2}{|c|}{ Examples of sustainable practices adoption } \\
\cline { 2 - 3 } & \multicolumn{1}{|c|}{ Before supplier development } \\
\hline practices & $\begin{array}{l}\text { Sustainability topics and knowledge are } \\
\text { communicated through irregular informal } \\
\text { interaction among employees. (S5) }\end{array}$ & $\begin{array}{l}\text { Employees communicate and discuss sustainability topics } \\
\text { and knowledge through a worker-community social media } \\
\text { app, which includes videos, blogs, and a confidential } \\
\text { channel to talk/complain about labour or ethical issues. (S5) }\end{array}$ \\
\cline { 2 - 3 } & $\begin{array}{l}\text { Water reuse rate was 53\% because chemicals in } \\
\text { water were difficult to remove. (S3) }\end{array}$ & $\begin{array}{l}\text { Water reuse rate increases to 85\% because of the upgraded } \\
\text { pipelines. Production-related water without certain } \\
\text { chemicals will go into a separate recycling system. (S3) }\end{array}$ \\
\hline
\end{tabular}




\begin{tabular}{|l|l|l|}
\hline \multirow{2}{*}{$\begin{array}{l}\text { Imitating sustainable } \\
\text { practices }\end{array}$} & $\begin{array}{l}\text { The hazardous waste was stored close to general } \\
\text { waste storage. (S2) }\end{array}$ & $\begin{array}{l}\text { Strict hazardous waste management protocols have been } \\
\text { developed, including a new separated storage specifically } \\
\text { for hazardous waste.(S2) }\end{array}$ \\
\cline { 2 - 3 } & $\begin{array}{l}\text { Cutting machines might hurt the hands of } \\
\text { workers if they were not careful enough. (S1) }\end{array}$ & $\begin{array}{l}\text { Install laser-sensors on cutting machines so that the cutting } \\
\text { will automatically stop when workers' hands cross a } \\
\text { line.(S1) }\end{array}$ \\
\hline $\begin{array}{l}\text { Toddling sustainable } \\
\text { practices }\end{array}$ & $\begin{array}{l}\text { No personal protection equipment (PPE) } \\
\text { provided (e.g., metal shoes to protect toes from } \\
\text { heavy loads), or wearing PPE was not } \\
\text { implemented very well among workers. (S6,S8) }\end{array}$ & $\begin{array}{l}\text { Ensure 100\% PPE provision and wearing, with proper } \\
\text { incentive mechanism for workers during hot seasons. } \\
\text { (S6,S8) }\end{array}$ \\
\cline { 2 - 3 } & $\begin{array}{l}\text { Air pollutants were directly released to } \\
\text { atmosphere during the coating process. (S4) }\end{array}$ & $\begin{array}{l}\text { Air pollutants were collected and filtered before } \\
\text { discharging, and the facility installed real-time monitor to } \\
\text { detect air pollutions. (S4) }\end{array}$ \\
\hline
\end{tabular}

4. Quotations on knowledge base and power relationships

\begin{tabular}{|l|l|}
\hline & Example Quotations \\
\hline Prior relevant knowledge & \\
\hline $\begin{array}{c}\text { Individual knowledge } \\
\text { - Education background of Gatekeepers; }\end{array}$ & $\begin{array}{l}\text { "My previous jobs mainly involve product quality control...thus I knew very little } \\
\text { about sustainability prior to the training." (S1) } \\
\text { "I've been managing health safety issues of the facility in the past eight years, } \\
\text { so I thought I knew a lot in practice. But this program provided a unique } \\
\text { opportunity to review them systematically."(S2) }\end{array}$ \\
\hline Organisational knowledge & "After ... (the American headquarter) purchased our company, sustainability \\
\hline
\end{tabular}


- Environmental management system (e.g. ISO 14000);

- Code of conduct as a company or business group;

- Previous experience in supplier development/compliance schemes

has been emphasized more than ever... but it was very challenging since you can't just replicate the (American) management system."(S2)

"We (the business group) have our own principles in sustainable management, but we are also collaborating with BCA so that this unit (facility) can become and remain a leader among our competitors."(S5)

"It has been our culture to remain proactive regarding governmental regulation or buyer requirement - compliance is never enough."(S8)

\section{Access to external knowledge}

\section{From buyers}

- Compliance requirements;

- Environmental and social standards;

- Return visits for audit purposes

"Buyer requirements can be extremely specific and in detail... and for most of time, we are too frustrated to make sure our manufacturing and operating teams understand and implement all those requirements" (S5)

"Although BCA is among the best in industry regarding sustainability practices, we are sometimes struggling when some requirement from other buyers conflicts with BCA's standards - for example, the minimum width of fire escape routes."(S6)

From peer suppliers

- Best practices and cases;

- Perceived risks and benefits of sustainable practices from peer suppliers or competitors

"The explosion in ... (city name) really triggered the safety concerns at company level."(S3)

"This program offers an excellent opportunity to talk to other companies which is not quite easy in our line of work. In and out of classroom, we really had a great time exchanging ideas and best practices on sustainability" (S3) "The best way to win my pollution control budget from my boss is to show him the news in which the director of ... (another factory) went to jail because of the pollution."(S4)

Other external sources

- Knowledge transfer and learning from different training opportunities (formal or informal)

"We have setup our own social media and blog account, which gives weekly updates on safety management and real industrial cases." (S2)

"My favourite trainer of this training program used to work at ... (a focal chemistry company), so her knowledge and cases of hazardous waste management are really helpful to me." (S1) 


\begin{tabular}{|c|c|}
\hline \multirow[t]{2}{*}{$\begin{array}{l}\text { sustainable practices, and have some level of reward and/or } \\
\text { coercive power to encourage sustainable practices, or to } \\
\text { correct unsustainable behaviours. }\end{array}$} & $\begin{array}{l}\text { after one auditing from buyers. Now they are more willing to listen because we } \\
\text { are making sense and we know how to make a difference about injury rate." } \\
\text { (S3) } \\
\text { "I showed them the math: yes, the refurbishment costed } 270 k \text {, but the ROI on } \\
\text { energy saving is so high that we can basically get the money back after three } \\
\text { months."(S6) }\end{array}$ \\
\hline & $\begin{array}{l}\text { "Communication and coordination is the key... Our team has no authorities over } \\
\text { operation and manufacturing, thus we have to win their trust, and let them } \\
\text { know we are not "looking for troubles'." (S7) } \\
\text { "I report to the environment committee of the business group, not only to the } \\
\text { operation director of the facility. That gives me some leverage to establish KPIs } \\
\text { to evaluate sustainability performance, which influences their (the } \\
\text { operation/manufacturing team) promotions."(S4) } \\
\text { "He (the Gatekeeper) is my actual right hand for the past ten years. When HQ } \\
\text { asked for a sustainability team, I put him in charge, and I trust and support his } \\
\text { judgement of adopting new practices in many cases if not all."(S1) }\end{array}$ \\
\hline
\end{tabular}

